\title{
Globalization and working conditions in developing countries
}

\author{
Ovidiu Andrei Cristian Buzoianu ${ }^{1 *}$, Mihaela Diana Oancea Negescu ${ }^{1}$, Victor Adrian \\ Troaca $^{1}$, and Carol Cristina Gombos ${ }^{1}$ \\ ${ }^{1}$ Bucharest University of Economic Studies, Assistant Teacher, PhD. Department of Management, \\ 6 Piata Romana, Sector 1, Bucharest, Romania
}

\begin{abstract}
.
Research background: In the last two decades, labor markets around the world have become increasingly integrated. Political change and economic reforms have transformed China, India, Indonesia and the former communist bloc countries, effectively involving their consistent workforce in market economies.

Purpose of the article: The aim of this paper is to offer globalization, a concept that identifies in the minds of many people with multinational companies and greedy capitalism and that would exploit anyone, a more humane image in terms of the beneficial effects it has on working conditions.

Methods: As it becomes more and more a contemporary reality, globalization becomes the most controversial concept in the international economic and political literature. In order to write this article, a methodology was used based on the analysis of demographic and socioeconomic statistics, analysis and interpretation of the literature, as well as conducting a case study on the impact of globalization of an emerging country, namely Indonesia. We live in a globalized world and yet there is still no consensus on what globalization means

Findings \& Value added: At the same time, the development of technologies, combined with the gradual removal of restrictions on crossborder trade and capital flows, have allowed production processes to be relocated away from target markets for an increasing number of products and services. The process of choosing the location of the production center has become more receptive to labor costs.
\end{abstract}

Keywords: globalization; labor market; companies; development

JEL Classification: $F 63 ; J 24$

\footnotetext{
*Corresponding author: buzoianuovidiu@yahoo.com
} 


\section{Introduction}

Globalization, defined as the removal of barriers to migration trade and overseas investment, directly affects workers in both developed and developing countries [1]. Even though most trade and investment takes place between industrialized countries, the growth rate of these interactions is higher in developing countries [2]. This situation presents both opportunities and risks for workers in poor countries. In the last two decades, labor markets around the world have become increasingly integrated [3]. Political changes and economic reforms have transformed China, India, Indonesia and the former communist bloc countries, effectively involving their consistent labor force in market economies. At the same time, the development of technologies, combined with the gradual removal of restrictions on cross-border trade and capital flows, have allowed production processes to be relocated away from target markets for an increasing number of products and services. The process of choosing the location of the production center has become more receptive to the relative costs of labor.

Some critics have said that the competitive pressure imposed by international competition is likely to create a downward trend in global labor standards. Antiglobalization advocates have frequently argued that globalization-induced competition causes firms to ignore labor standards in their efforts to reduce costs [4]. This is one of the many concerns of the population and causes a negative attitude towards the process of globalization. This paper seeks to provide evidence to combat the various negative scenarios, both through an analysis of the literature in the field and through country-level measurements. Indonesia is chosen as the country studied because it is one of the largest labor markets and the relatively short interval of the liberalization process could more easily highlight some of the effects of globalization on working conditions.

The aim of this paper is to provide globalization, a concept that identifies in the minds of many people with multinational companies and greedy capitalism and that would exploit anyone, a more humane image in terms of the beneficial effects it has on working conditions around the world. and especially in developing countries. As it becomes more and more a contemporary reality, globalization becomes the most controversial concept in the international economic and political literature. We live in a globalized world, and yet there is still no consensus on what globalization means.

\section{Methods}

This article deals with the assumption influenced by globalization in terms of the global labor force, as well as the internal and external policies of states. In the realization that it is possible to analyze specialized literary analyzes on the one hand, but if one analyzes past, present and future data (estimation), provided by the World Labor Organization. Measurement tools and procedures can be measured for all important or reasonable features. Analyze after a detailed realization, provided that appropriate techniques can be analyzed.

\section{Results}

Even after two waves of globalization, one at the end of the 19th century and the other since the end of the Second World War, the effects of opening markets to international competition on working conditions remain a hotly debated topic. The debate is important because the link between international economic integration and employee welfare conditions both national and international policies. As the history of the two waves 
demonstrates, the political response to the consequences, real or perceived, of a more advanced integration on working conditions restricts this process.

Discussions about the link between globalization and working conditions involve a confrontation of two ideas, between the predictions of international trade theories on the one hand and different RTTB ("race to the bottom") scenarios on the other. Predictions of international trade theories are known to economists, but not widely understood by the general public. In the second wave of globalization, the discussion widened to include workers' rights. In contrast to theories of international trade, opponents of globalization often argue that free trade and multinational companies increase international inequality and have devastating effects on the conditions and rights of workers in developing countries. At the heart of these statements are RTTB scenarios in which companies in developing countries would degrade working conditions and workers' rights in order to compete effectively in international markets [5]. These scenarios also claim that governments suppress workers' rights to attract foreign investment. In these, globalization creates low wages, increased working hours, insecure conditions and suppresses workers' rights.

During the last decade of the twentieth century, a wide-ranging improvement in working conditions and workers' rights has been accompanied by a significant increase in the number of countries with liberal trade policies, large volumes traded, and high FDI flows [6]. Wages have risen, the number of hours has fallen, and safety has improved. The debate provoked by the confrontation of the two ideas often takes place without resorting to evidence about the effects of economic integration on working conditions around the world.

\subsection{Trade liberalization and working conditions}

If we want to isolate the effects of trade and other mechanisms of globalization on working conditions, it is useful to consider how they evolve in closed economies. It should come as no surprise that the most important influencing factor is the level of development of the country. At any given time, countries with higher GDP / place tend to have higher wages, shorter working hours and safer jobs. [7]. Countries with high national incomes also tend to have higher civil rights, freedom of association, low levels of child labor [8]. Over time, rapidly developing countries feel the greatest progress in working conditions. To a large extent, the inequality in income, working conditions, workers' rights observed in the world results from differences in the level of development [9].

Improving economic growth in poor countries encourages the development of working conditions [10]. Recognizing the strong role of development opens up a wide variety of policies available for improving working conditions [11]. Even in a closed economy, working conditions can be improved through faster technical progress, investments in physical and human capital $[12,13]$. The question is whether these conditions are improving faster in countries participating in international economic integration. [14]. A simple implication is that if we consider trade liberalization a positive factor in increasing national income per capita, then trade itself becomes a mechanism for improving workers' conditions and rights. Recent literature has shown that trade liberalization tends to improve economic growth. This is an indirect effect of globalization on working conditions.

Emphasizing the important role of economic growth and development must not obscure the significant variations around this relationship. Countries at the same level of development may have different working conditions. The fact that some countries have the level of working conditions uncorrelated with that of development suggests that there are other factors [15].

Forecasts from international trade theories say that free trade will indirectly improve working conditions by increasing national per capita income [17]. The principle of 
competitive advantage provides that free trade will result in a reallocation of resources to more efficient use, increasing national income as countries export relatively abundant goods and import goods produced from relatively limited resources (of any kind) nationally. By eliminating the obligation to meet national consumption needs with domestic goods, trade allows resources to be allocated to activities where their productivity is relatively high. Even countries with similar resources can benefit from trade through mass production. High efficiency allow for better monetary and non-monetary compensation [18].

In the standard view, unskilled labor is the factor of abundant production in developing countries and capital and skilled labor in developed countries. In this vision, trade liberalization should reduce wage inequality in premiums and increase it in developed ones.

Recent studies show that this scenario is not always true. When trade is designed to transfer technologies designed in developed countries for skilled labor from there to developing countries, it creates a demand for skilled labor [19].

Contrary to the predictions in the theories of trade is the notion of RTTB which says that free trade will diminish the conditions and rights of workers in the exporting sectors of integrated countries [20]. How trade should worsen working conditions is not very clear. Free trade policies increase foreign demand for products exported by that country and implicitly for the services of workers who produce those goods. What happens to nonmonetary wages and working conditions then depends on the supply situation on the labor market, which in turn is determined by workers' alternatives.

Where high unemployment is present, the increase in exports will increase employment without necessarily increasing working conditions. This may be the case in poor countries with many agricultural workers in rural areas and many unemployed in urban areas. Even in this case, workers will feel an improvement in conditions if they were inferior in the sector from which they come.

For economies with a low unemployment rate, exporting firms, in order to cope with increased demand for products, will have to attract workers from other places by offering better working conditions than in other sectors [21].

\subsection{Globalisation in Indonesia}

Among the multitude of possible definitions of globalization, this section focuses on trade and foreign direct investment (FDI) as these were the areas targeted by government liberalization reforms. Most of the investment was made in certain industries: textiles / garments dominated the first wave and the chemical and manufacturing wave in subsequent waves. Moreover, as in other developing countries, foreign investment was clearly foreignoriented, with the intention of producing goods for export.

During the import substitution policy, the government invested heavily in heavy industry, petrochemicals and mining. The initial goal of liberalization in Indonesia was to attract FDI and promote exports to diversify the heavily oil-dependent economy. The strategy consisted of three main components: trade liberalization, investment reform and changes in industrial policy.

Although Indonesia has joined various regional and global liberalization initiatives such as the AFTA and the WTO, most of the liberalizations undertaken by Indonesia have been unilateral. In addition to tax cuts and the number of tax levels, the government has also simplified customs procedures [22]. These sustained reforms have had a strong psychological effect on business circles and have increased confidence in the government's intention to further implement a liberalization policy.

Non-tariff barriers to many goods such as electronics and appliances have been removed. These are now imported under the unrestricted regime of general goods. All these 
measures induced by the liberal spirit have generated an increase in exports and imports which have been the basis of the rapid economic growth of the last period. The flow of FDI, coming from Japan, Singapore, South Korea, Taiwan and Hong Kong, has also brought the technical, managerial and marketing skills needed to produce competitive goods for the global market.

Thus, Indonesia has connected at a very fast pace to the world trade market by incorporating local producers into foreign chains of distributors and manufacturers. This evolution of investments was followed by a threefold increase in exports of confectionery. The liberalization of foreign trade has been accompanied by other reforms at the national level. Thus Indonesia reduced government control and eliminated monopolies in telecommunications, air transportation, and financial services. Attempts have been made to introduce competition in some segments for greater investment diversification.

Table 1. Empirical analysis of working conditions in Indonesia

\begin{tabular}{|l|c|c|c|c|}
\hline & $\mathbf{2 0 0 0}$ & $\mathbf{2 0 0 5}$ & $\mathbf{2 0 1 0}$ & $\mathbf{2 0 1 8}$ \\
\hline Total employeers (mil) & 2.86 & 3.57 & 4.21 & 4.92 \\
\hline Foreign & 9 & 15 & 19 & 24 \\
\hline Local private & 82 & 80 & 78 & 72 \\
\hline Public & 9 & 8 & 7 & 8 \\
\hline Employeers/enterprise & 161 & 197 & 183 & 210 \\
\hline Foreign & 368 & 545 & 696 & 519 \\
\hline Local private & 145 & 178 & 163 & 188 \\
\hline Public & 432 & 738 & 595 & 521 \\
\hline V.A/employeers & 11 & 17 & 28 & 45 \\
\hline Foreign & 25 & 29 & 39 & 74 \\
\hline Local private & 10 & 16 & 19 & 38 \\
\hline Public & 9 & 15 & 22 & 32 \\
\hline Foreign / local ratio & 2.6 & 1.8 & 2.5 & 2.8 \\
\hline
\end{tabular}

Source: Data on medium and large companies taken from national statistics in Indonesia

Due to a high dependence on the import of raw materials, the low value added from certain resource-based areas and an almost non-existent capital market, the possibilities for vertical integration have been reduced. Moreover, the small range of exported products and the unique specialization in products that require a high degree of labor processing have limited the possibilities for export expansion. The companies also suffered from internal problems. Low productivity of small and medium enterprises, high concentration in some segments, poor human resources, technological support and low production capacity of national firms have hampered economic growth [23].

As a result, the government continues to try to attract foreign direct investment. Since 2007 , foreign and domestic companies have been treated equally by the government, which has ensured better law enforcement. But small and medium-sized businesses are constantly protected. Another improvement brought in 2007 is the protection of nationalization of foreign enterprises and the prioritization and facilitation of investments in the production of goods that require a high degree of processing with labor.

Indonesia's experience with globalization has several main features. First of all, during the recent reform period, foreign trade and investment policies have been designed to complement each other. Second, Indonesia has experienced distinct periods of inflows and outflows of foreign capital. These periods can be contrasted to provide some evidence of the effects of globalization on working conditions. In the next subchapter we analyze the factors that have shaped working conditions in Indonesia. 


\subsection{Anti-sweatshop activity in Indonesia}

Some critics have said that competitive pressure from international competition is likely to create a downward trend in global labor standards. Anti-globalization advocates have frequently argued that globalization-induced competition causes firms to ignore labor standards in their efforts to reduce costs [24]. Exporters facing the challenges of the world market, as well as multinational firms facing cheap imitators from low-wage regions, could, in an attempt to remain competitive, reduce costs by paying lower wages, hiring children or by creating conditions. sanitary ware for their workers. From this perspective, globalization is likely to undermine national efforts to impose some labor standards. Even if countries succeed in enacting laws that introduce, or raise, labor standards, global pressure could prevent companies from complying with them. This seems to be the case when the penalties for non-compliance are low. In such circumstances, labor law provisions, such as the minimum wage, could be seen as simple guidelines for setting wages.

But looking at things from a different perspective, human rights organizations have focused more on the behavior of exporting and multinational companies. Anti-sweatshop campaigns launched to improve working conditions in poor countries have grown substantially since the 1990s. The term "sweatshop" is attributed to those working conditions considered difficult, dangerous and without proper facilities and poorly paid. The emergence of a global anti-sweatshop movement coupled with the rapid growth of trade in goods and services suggests that globalization would have two contradictory effects. While firms may want to reduce labor costs in the face of international competition, new human rights movements may prevent them from doing so. Even if there are no clear international penalties for deviations from labor law, the potential effects on the company's reputation are significant. Giant corporations with strong brands such as Nike, Reebok, Adidas and Gap have been targeted by well-coordinated boycott campaigns across hundreds of university campuses.

To measure the impact of the anti-sweatshop movement on the labor market, we compare certain levels before and after their production. The combined effects of the minimum wage legislation and anti-sweatshop campaigns have led to a real increase of more than $50 \%$ and a doubling in nominal terms of the salary of unskilled workers in the companies covered by those actions. We then examine whether the increased wages caused redundancies or relocations. Despite a significant non-adoption rate, the increase in the minimum wage led to a $12 \%$ reduction in the employment rate of unskilled workers. Targeted anti-sweatshop activities on footwear and clothing companies did not have this negative effect. Even if some enterprises were closed, this was counteracted by employment in other enterprises [25]. The fact that wages have risen under the pressure of activism without noticeable layoffs suggests that anti-sweatshop campaigns have succeeded in helping skilled workers. These results suggest that activism has had less costly consequences than US pressure.

Organizations such as the Global Exchange, the Press for Change and the National Labor Committee have used this impulse, generated by media attention to poor conditions at Nike factories in Indonesia, to create an international campaign against sweatshp weather conditions at Nike factories.

These campaigns contained advertisements that satirized Nike and their slogans. The activists waged a P.R war against Nike and other major manufacturers in the field. The movement in the US and Europe was stimulated through electronic forums where activists gathered, exchanged information at high speed, and planned the next actions.

Nike introduced its own Code of Conduct in 1992 to be in line with international labor standards, but it was not fully implemented until the mid-1990s. Meanwhile, NGOs 
persistently maintained their assessments of working conditions in Nike factories in order to hold the company accountable for poor employee conditions. The campaign against Nike in Indonesia was essentially a media campaign that operated through contacts with major newspapers and television stations that were used to draw attention to the plight of Indonesian workers. The latter were brought to the United States to talk about the conditions there. The campaign focused on Nike, Reebok and Adidas as these 3 giants own over $50 \%$ of the global equipment market.

The campaign against Nike subcontractors was focused almost exclusively on Indonesia because it had the second largest market after China. There is no study in China that reflects certain irregularities and Jeff Belliger's study had already fueled the view that there are problems in Indonesia. Other elements that contributed to this concentration in Indonesia were the local support of NGOs and the use of the Internet for gathering information. All this was possible due to the more open political regime compared to that of China.

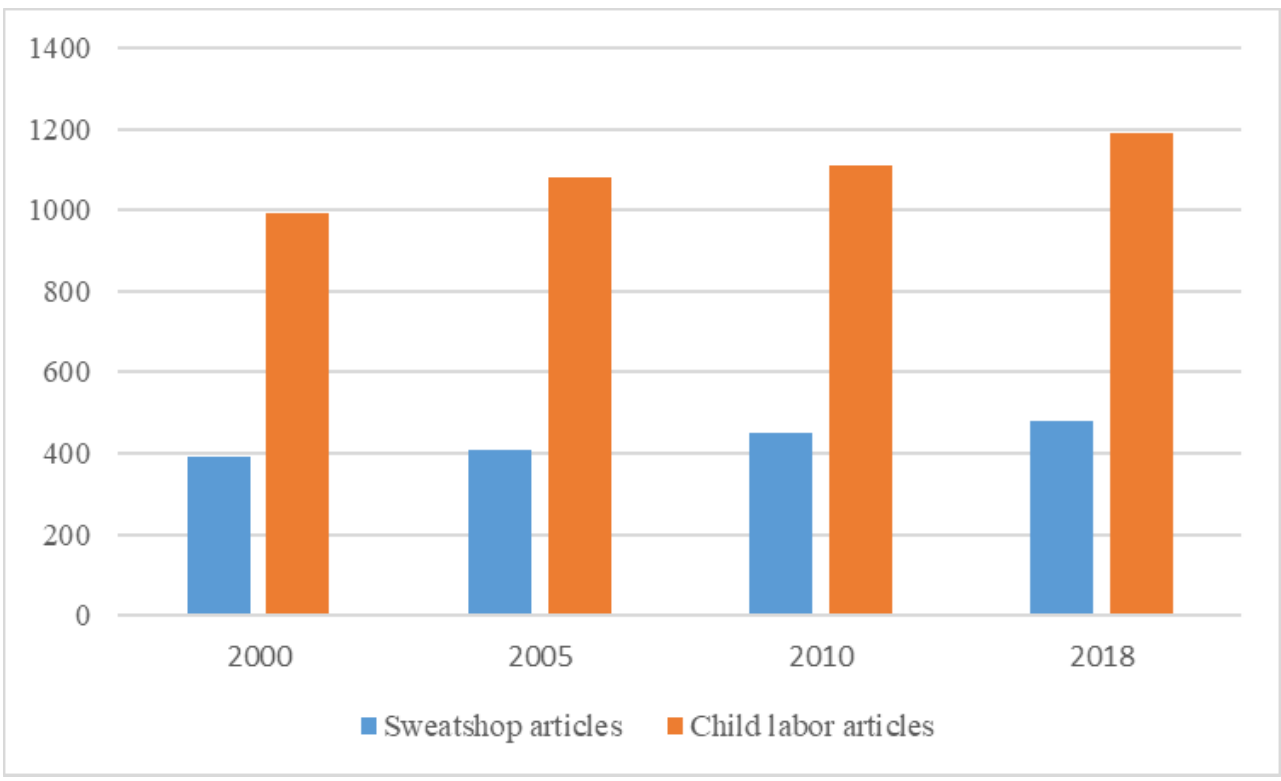

Fig. 1. Anti-sweatshop activity in Indonesia

Source: Data on medium and large companies taken from national statistics in Indonesia

To summarize, the "treatment" began with a series of studies on foreign and exportoriented companies in Indonesia, and culminated in negative publicity about conditions and wages through a variety of channels, including major newspapers, websites, public speeches and actions. television. One way to estimate the size of interest is the number of articles published about working conditions in the 1990s.

\subsection{Qualitative measurements on working conditions}

The results of the previous section are compatible with the idea that FDI in export-oriented activities has generated an inter-industrial reorientation from agriculture to certain manufacturing sectors. The effect that this change has on non-wage working conditions depends on the conditions in the manufacturing sector which are or are not better than in agriculture. Sakernas labor market surveys contain specific questions about working conditions, including questions about income, available facilities, medical benefits, safety, transportation and an overall assessment. Subjects are given four categories to describe 
each characteristic and are asked if each condition is better, just as good, just as bad, worse than it was a year ago.

After analyzing these data, the research institute built an index for each industry and then compared them with that of textiles / clothing. The positive coefficients indicate that the respondents in that sector indicated higher values in the survey than those in textiles / clothing, which suggests that the characteristic of working conditions is better. For example, finance / insurance / real estate workers ranked "facilities" with a higher score than those in textiles / clothing. Construction and mining workers scored lower "safety" than those in textiles / clothing.

Table 2. Qualitative measurements on working conditions

\begin{tabular}{|l|r|c|c|r|}
\hline \multicolumn{1}{|c|}{ Sector } & Facilities & Medical benefits & \multicolumn{1}{l|}{ Safety } & \multicolumn{1}{|c|}{ General } \\
\hline Agriculture & -0.568 & -0.398 & -0.449 & -0.285 \\
\hline Mining & -0.181 & -0.118 & -0.098 & 0.038 \\
\hline Food/alcoholic beverages/tobacco & 0.082 & 0.085 & 0.049 & 0.079 \\
\hline Woodworking & -0.055 & -0.091 & -0.092 & -0.008 \\
\hline Others industries & 0.062 & 0.053 & 0.074 & 0.081 \\
\hline Construction & -0.382 & -0.476 & -0.434 & -0.176 \\
\hline Finance / Insurance / Real Estate & 0.234 & 0.172 & 0.097 & 0.240 \\
\hline Public administration & 0.234 & 0.190 & 0.141 & 0.272 \\
\hline
\end{tabular}

Source: Data on medium and large companies taken from national statistics in Indonesia

One of the main concerns is to see if the wage differences analyzed earlier represent compensatory differentials. That is, if the higher salary in textiles / garments is a compensation for the worse conditions. After an analysis of the wage gap and the general index, a positive link was found, suggesting that the higher wage is not an indicator for poor general working conditions.

The basic idea from these analyzes is that the expanding manufacturing industries, textiles / garments and "other industries", have better wages and working conditions than in agriculture. To the extent that FDI has induced a shift from agriculture to these industries, there is no evidence that globalization has led to declining working conditions in Indonesia. On the contrary, it is likely that these conditions have improved for those who have changed the sector.

\section{Discussion and conclusion}

During the last decades of the twentieth century the significant expansion of international trade was followed by a general improvement of labor rights and conditions. Some of these improvements would have been due to the fact that countries would have increased their per capita income without increasing trade flows. But insofar as the exchange helps to increase income, it also implicitly improves working conditions. The improvement of working conditions during globalization is in line with the general predictions in the theories of international trade. Both global and Indonesian data largely reject so-called RTTB scenarios in which companies in developing countries would degrade working conditions and workers' rights in order to compete effectively in international markets. 
In the 1990s, anti-sweatshop activists stepped up their efforts to improve the working conditions of workers in developing countries. Due to the strong image of some multinational companies, the campaign focused mainly on Indonesia. The "treatment" began with a series of studies on foreign and export-oriented companies in Indonesia, culminating in negative publicity about conditions and wages through a variety of channels, including major newspapers, websites, public speeches and televised actions. These actions and international pressure played a significant role in enacting laws that would improve working conditions in Indonesia.

Globalization brings both benefits and dangers for workers in developing countries and this paper focused on several specific aspects of working conditions in Indonesia: interindustrial wage disparities and other qualitative measures of working conditions. It has been found that policy reform has successfully attracted foreign investment in export activities, and that this investment has been concentrated in a small number of areas of manufacturing. As FDI increased, the percentage of employment and wage disparities recorded by these industries increased relative to other sectors, and importantly to agriculture. Analysis of working conditions in the exporting and receiving FDI sectors found that they are superior to those in agriculture, often the only alternative for many Indonesian workers. When the crisis hit Indonesia, these trends reversed: as FDI declined, wages in sectors positively affected by FDI fell, and the percentage of agricultural workers increased. Overall, these results are in line with the hypothesis that FDI and trade liberalization, both major forms of globalization, have contributed to the transfer of low-paid and lower-paid workers to betterpaid and improved sectors.

\section{References}

1. Auer, R., Borio, C., Filardo A. (2017, January). The Globalisation of Inflation: the Growing Importance of Global Value Chains. Retrieved from : https://www.bis.org/publ/work602.htm

2. Bran, F., Rădulescu, C. V., Bodislav, D. A., Burlacu, S. (2020). Environmental risks in the context of globalization. Economic Convergence in European Union, 350.

3. Haider Zaidi S., Zixiang W., Muhammad W., FujunHou Y., (2019). The impact of globalization, natural resources abundance, and human capital on financial development: Evidence from thirty-one OECD countries. Resources policy, 64, 101476.

4. De Haan J., Sturm, J. E. (2017). Finance and income inequality: a review and new evidence. European Journal of Political Economy, 50, 171-195.

5. Sitalaksmi, S., Robertson, R. (2008). Globalization and Working Conditions: Evidence from Indonesia. from https://citeseerx.ist.psu.edu/viewdoc/download?doi=10.1.1.485.5485\&rep=rep1\&type= pdf

6. Graafland J., Lous B. (2018). Economic freedom, income inequality and life satisfaction in OECD Countries. Journal of Happiness Studies, 19(7), 2071-2093.

7. Furceri, D., Loungani, P. (2018). The distributional effects of capital account liberalization. Journal of Development Economics, 130, 127-144.

8. Dima, C., Burlacu, S., Buzoianu, O. A. C. (2020). Strategic Options for the Development of Ecotourism in the Danube Delta in the Context of Globalization. In T. Kliestik (Ed.), The 19th International Scientific Conference Globalization and its Socio-Economic Consequences 2019 - Sustainability in the Global-Knowledge Economy. Rajecké Teplice. 
9. Alpopi, C., Burlacu, S., Ioviţu, M. (2018, September). Procesul de globalizare şi politicile ecologice. $\quad$ Retrieved from http://irek.ase.md/xmlui/bitstream/handle/1234567890/716/Alpopi_C_Burlacu_S_Iovit u_M_\%20conf_09.18.pdf? sequence=1\&isAllowed=y

10. Flanagan, R. J. (2007, May). Globalization, Working Conditions, and Labor Rights: Implications for Developing Countries. Retrieved from : https://siepr.stanford.edu/sites/default/files/publications/345wp.pdf

11. Burlacu, S., Bodislav, D. A., Rădulescu, C. V. (2018). E-commerce and global food resources. Managerial Challenges of the Contemporary Society, 11(2), 48.

12. Faggianelli, D., Burlacu, S., Carra, C. (2018). Victimization of Health Professionals in Bucharest Service Relations and Social Work Relationships. Administratie si Management Public, 30, 109-126.

13. Carra, C.; Burlacu, S.; Faggianelli, D., (2017). Violence In Health Organizations In Romania. Proceedings of Administration and Public Management International Conference (pp. 51-59). Bucharest.

14. Goldberg, P., Pavcnik, N. (2007). Distributional Effects of Trade Liberalization in Developing Countries'. Journal of Economic Literature, 45(1), 39-82.

15. Setzler, B., Tintelnot, F. (2019, August). The effects of foreign multinationals on workers and firms in the United States. Retrieved from : https://www.nber.org/system/files/working_papers/w26149/w26149.pdf

16. Katircioğlu, S. (2020). Role of financial development in economic globalization: evidence from global panel. Applied Economics Letters, 7(5), 371-377.

17. Burlacu, S., Gutu, C., Matei, F.O. (2018). Globalization - Pros and cons. QualityAccess to Success, 19, 122-125.

18. Jessop, B. (2016). The developmental state in an era of finance-dominated accumulation. In Y.-W. Chu (Ed.), The Asian developmental state: Reexaminations and new departures (pp. 27-55). Basingstoke, UK: Palgrave Macmillan

19. Harrison A., Scorse J. (2003). Globalization's impact on compliance with labor standards. Retrieved from : https://mpra.ub.unimuenchen.de/36450/1/MPRA_paper_36450.pdf

20. Heintz J. (2011). Global labor standards: their impact and implementation. In J. Michie (Ed.), Handbook of Globalisation. Edward Elgar Publishing Inc.

21. Van Treeck K., Wacker Konstantin. M. (2019). Financial globalisation and the labour share in developing countries: The type of capital matters. World Economy, 43(9), 2343-2374.

22. Reiche, B. S, Lee, Y., Allen, D. G. (2018). Actors, Structure, and Processes: A Review and Conceptualization of Global Work Integrating IB and HRM Research. Journal of Management, 45(2), 359-383.

23. Lee C. C. (2018). The impact of country risk on income inequality: a multilevel analysis. Social Indicators Research, 136(1), 139-162.

24. Eckel, J. C., Neary P. J. (2010). Multi-Product Firms and Flexible Manufacturing in the Global Economy. The Review of Economic Studies, 77(1), 188-217.

25. Agrippino S. M, Rey H. (2020). U.S. Monetary Policy and the Global Financial Cycle. The Review of Economic Studies, 87(6), 2754-2776. 